
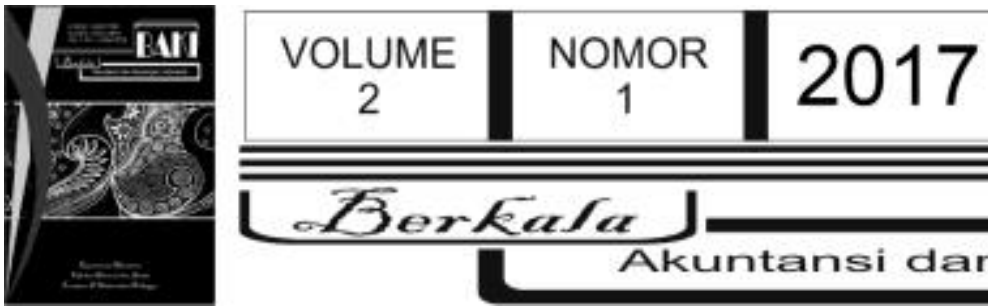

Lorka/a 1

\title{
Manajemen Laba dan Pengungkapan Tanggung Jawab Sosial Perusahaan dengan Komisaris Independendan Kepemilikan Institusional sebagai Variabel Pemoderasi
}

\section{Carolyn Lukita Sembiring ${ }^{1}$}

${ }^{1}$ STIE Perbanas Surabaya

carolyn.lukita@perbanas.ac.id

\begin{tabular}{l}
\hline I N F O ARTIKEL \\
\hline Histori Artikel: \\
Tanggal Masuk 2 Februari 2017 \\
Tanggal Diterima 23 Februari \\
2017 \\
Tersedia Online 9 Mei 2017 \\
\hline Kata Kunci: \\
manajemen laba; \\
pengungkapan CSR; \\
komisaris independen; \\
kepemilikan institusional
\end{tabular}

ABSTRAK

Penelitian ini menguji pengaruh pengungkapan tanggung jawab sosial perusahaan terhadap tindakan manajemen laba, yaitu apakah perusahaan yang memiliki kepedulian yang tinggi terhadap tanggung jawab sosial dan lingkungan, akan mengurangi kecenderungan manajemen laba, yang justru berpotensi melemahkan kepercayaan investor terhadap kinerja manajer. Penelitian ini juga meneliti variabel pemoderasi yaitukomisaris independen dan kepemilikan institusional, yang diduga dapat memperkuat pengaruh negatif antara pengungkapan CSR dan manajemen laba, dengan menggunakan perusahaan pertambangan yang terdaftar di BEl sebagai sampel, karena sektor pertambangan merupakan sektor yang paling berpotensi merusak lingkungan. Analisis regresi digunakan untuk menguji hipotesis. Hasil penelitian menunjukkan bahwa keseluruhan hipotesis terdukung, pengungkapan CSR berhubungan signifikan negatif dengan manajemen laba. Hal ini menunjukkan bahwa jika perusahaan mengungkapkan akuntabilitas sosial yang lebih luas (seperti pengungkapan CSR), maka manajemen laba akan menurun, karena perusahaan yang memiliki pengungkapan yang lebih luas menunjukkantransparansi yang lebih baik, dapat dipercaya dan berkomitmen terhadap sosial dan lingkungannya, sehingga cenderung tidak melakukan manajemen laba yang justru dapat merusak kepercayaan tersebut. Penelitian ini juga berhasil membuktikan bahwa komisaris independen dan kepemilikan institusional terbukti dapat menguatkan hubungan negatif antara CSR dan manajemen laba.

\section{Pendahuluan}

Pelaporan laba memegang peran penting dalam evaluasi kinerja perusahaan. Pentingnya pelaporan angka laba pada evaluasi kinerja perusahaan, menyebabkan banyak perusahaan 
yang mencoba untuk menyesatkan investor atau pemilik dalam pengambilan keputusan dan mengambil keuntungan dari kurangnya informasi yang diterima oleh investor (Hong dan Andersen 2011). Salah satu cara yang sering digunakan adalah manajemen laba. Manajemen laba merupakan pilihan yang dilakukan oleh manajer atas kebijakan akuntansi atau tindakan nyata manajer yang mempengaruhi laba untuk mencapai tujuan spesifik atas laba yang dilaporkan (Scott 2012).

Manajemen laba merupakan tindakan yang bertentangan terhadap etika dan moral dalam pelaporan, karena bertujuan untuk menyesatkan pengambilan keputusan oleh pemangku kepentingan berdasarkan laba yang dilaporkan. Tindakan manajemen laba yang dilakukan manajer dapat mengurangi kepercayaan pemangku kepentingan dalam penilaian kinerja perusahaan. Penurunan kepercayaan pemangku kepentingan, akan mendatangkan konsekuensi bagi perusahaan, sepertitekanan dari investor, ancaman perilaku yang tidak diinginkan karyawan, kesalahpahaman dari pelanggan,penghentian rekan kerja dari perusahaan, gugatan dari aparat, boikot aktivis, sinis dari pandangan masyarakat, dan pengungkapan media yang pada akhirnya akan menghancurkan reputasi perusahaan (Fombrun et al. 2000). Konsekuensi jangka panjang atas kurangnya kepercayaan pemangku kepentingan adalah hilangnya dukungan yang mengarah pada peningkatan kewaspadaan dan kecurigaan pemegang saham, juga meningkatkan biaya agensi (Zahra et al. 2005).

Perkembangan saat ini menunjukkan bahwa investor tidak hanya membutuhkan akuntabilitas dan evaluasi kinerja perusahaan melalui laporan laba saja, tetapi juga mempertimbangkan laporan pertanggungjawaban perusahaan untuk karyawan, masyarakat dan lingkungan. Investor juga mempertimbangkan pengungkapan tanggung jawab sosial dalam evaluasi kinerja perusahaan, sehingga menuntut transparansi dalam pelaporan kinerja sebagai komponen penting, seperti pengungkapan corporate social responsibility (CSR) yang menyediakan transparansi dan akuntabilitas yang lebih baik. CSR adalah proses untuk mengkomunikasikan dampak operasi perusahaan kepada kelompok tertentu baik pemangku kepentingan, dampak terhadap masyarakat sosial dan juga lingkungan (Hackston dan Milne 1996). CSR mencerminkan komitmen perusahaan untuk memperhitungkan dampak dari operasi perusahaan bagi sosial, ekonomi, dan lingkungannya, tanggung jawab sosial menunjukkan bahwa perusahaan yang melakukan kegiatan CSR yang tinggi merupakan perusahaan yang memiliki komitmen yang kuat untuk lingkungan (Hong dan Andersen 2011).

Etika memegang peran penting dalam proses komunikasi dan transparansi dalam pelaporan kinerja perusahaan. Shlefer (2004) menyatakan bahwa manipulasi laba merupakan tindakan yang bertentangan terhadap etika pelaporan, sedangkan pelaporan CSR menunjukkan bahwa perusahaan tersebut adalah perusahaan yang etis dan memiliki rasa tanggung jawab terhadap lingkungan, oleh karena itu perusahaan yang memiliki pengungkapan CSR atau memiliki komitmen yang kuat untuk tanggung jawab sosial cenderung tidak terlibat 
dalam manajemen laba. CSR mencerminkan transparansi yang dapat mengurangi prilaku oportunistik manajer untuk tindakan manajemen laba.

Penelitian terdahulu menunjukkan hasil yang berbeda atau adanya pertentangan arah hubungan antara manajemen laba dan CSR. Beberapa penelitian terdahulu menyatakan bahwa terdapat pengaruh positif antara CSR dan manajemen laba, namun penelitian lain justru membuktikan adanya pengaruh negatif antara pengungkapan CSR dan manajemen laba. Manajer dapat memiliki insentif untuk melakukan kegiatan CSR sebagai bentuk pencitraan dan pertahanan terhadap reaksi monitoring dari pemangku kepentingan yang dapat mengancam posisi manajer dan merusak reputasi perusahaan, yang disebabkan oleh hilangnya kepercayaan dari para pemangku kepentingan terhadap manajer karena manajemen laba yang dilakukan manajer (Prior et al. 2008), namun di sisi lain pengungkapan kegiatan CSR dalam laporan tahunan mereka akan membuat informasi keuangan menjadi lebih jelas dan transparan. Menurut Kim et al.(2012), pelaporan CSR merupakan pelaporan dari aktivitas tanggung jawab sosial yang umum bagi investor, pelanggan, dan pihak stakeholder lainnya untuk menuntut transparansi yang lebih besar mengenai semua aspek bisnis, sehingga dengan adanya pelaporan CSR laporan tahunan menjadi lebih terpercaya bagi investor maupun pihak yang menggunakan laporan tersebut dalam pengambilan keputusan.

Perusahaan yang bertanggungjawab secara sosial, bersedia mengeluarkan upaya dan sumber daya untuk menerapkan kegiatan CSR dan berusaha untuk memenuhi harapan etis dari pemegang saham dalam masyarakat, cenderung membatasi penggunaan manajemen laba. Sehingga memberikan investor informasi keuangan yang lebih transparan dan dapat diandalkan. Kim et al. (2012) menyatakan hubungan antara kinerja CSR dan pelaporan dan manajemen labadapat menjadi pertanyaan penelitian yang penting karena inkonsistensi hasil penelitian sebelumnya.Kim et al.(2012) menyatakan bahwa ketidakkonsistenan hasil penelitian CSR terdahulu karena adanya dua teori yang bertentangan (competing theories) yang memberikan prediksi yang berbeda tentang arah hubungan antara tingkat pelaporan CSR, tingkat kinerja CSR, dan manajemen laba. Dua teori yang bertentangan tersebut adalah teori berbasis ekonomis (economic-based theory) dan teori berbasis sosial-politis (socio-political theory). Clarkson dan Richardson (2008) menunjukkan bahwa teori berbasis ekonomi (economic-based theory) yang dapat menjelaskan hubungan antara tingkat pelaporan CSR dan tingkat kinerja CSR, sedangkan hasil dari Kim et al. (2012) menunjukkan dukungan empiris untuk teori sosial-politik (socio-political theory) yang menyatakan bahwa perusahaan melakukan CSR dengan premis bahwa keputusan bisnis dan hasil, termasuk dampak positif dan negatif yang disebabkan oleh perusahaan tidak hanya dirasakan oleh perusahaan dan pemangku kepentingan, tetapi juga publik secara luas, sehingga setiap keputusan yang diambil tidak hanya mempertimbangkan motivasi ekonomi saja, tetapi juga mempertimbangkan dampak lingkungan yang ditimbulkan. 
Hubungan antara CSR dan manajemen laba dalam konteks Indonesia yang masih menjadi pertanyaan penelitian, mengenai generalisasi dari temuan penelitian sebelumnya. Hal ini terjadi karena faktor sosial, politik, budaya, dan ekonomi dan faktor regulasi CSR yang berbeda. Perbedaan dalam konteks kelembagaan, Indonesia dikategorikan sebagai negara cluster codelow dengan tingkat perlindungan yang lemah terhadap investor, dapat membatasi generalisasi temuan penelitian terdahulu terkait CSR dan manajemen laba dalam konteks Indonesia (Leuz et al. 2003). Dalam beberapa tahun terakhir sebagian besar perusahaan Indonesia menunjukkan peningkatan dalam kegiatan dan pengungkapan CSR (Sari2013). Perusahaanperusahaan di Indonesia semakin aktif dalam melakukan kegiatan CSR setelah terbitnya UU Nomor 40 tahun 2007 tentang perseroan terbatas yang isinya mewajibkan perusahaan menjalankan bisnis mereka di bidang yang berhubungan dengan sumber daya alam untuk melaksanakan tanggung jawab sosial dan lingkungan. Pemerintah semakin menekankan tentang penitingnya tanggung jawab sosial ini pada PP 47 Tahun 2012 tentang tanggung jawab perusahaan perseroan terbatas untunk sosial dan lingkungannya. Namun standar akuntansi keuangan Indonesia belum mewajibkan perusahaan untuk mengungkapkan informasi sosial, akibatnya yang terjadi didalam praktik perusahaan hanya dengan sukarela mengungkapkannya. Walaupun aturan tentang kewajiban CSR sudah jelas, namun pengawasan atas pelaksanaan CSR belum ada. Hal ini menimbulkan keberagaman bentuk dan tingkat intensitas pelaksanaan CSR yang bervariasi pada perusahaan-perusahaan di Indonesia.

Dewan komisaris dapat memberikan pengaruh yang cukup kuat untuk menekan manajer untuk mengungkapkan CSR. Jaggi et al.(2009) menemukan bahwa tingginya proporsi komisaris independen dapat menurunkan manajemen laba akrual yang dilakukan oleh manajer. Komisaris independen akan menjalankan proses monitoring yang lebih efektif terkait manajemen laba. Monitoring yang dilakukan menunjukkan bahwa dewan komisaris yang independen memiliki kecenderungan menghalangi manajer untuk melakukan manajemen laba, sehingga kualitas laba yang dilaporkan menjadi lebih tinggi. Jo dan Harjoto (2011) menunjukkan bahwa diantara berbagai atribut tata kelola perusahaan, persentase dewan independen memiliki tingkat signifikansi dan memiliki korelasi positif yang paling tinggi, terkait dengan keputusan mengenai kegiatan CSR perusahaan. Fama dan Jensen (1983) menyatakan bahwa komisaris independen dapat menjadi monitoring yang penting atas prilaku top manajer. Dewan komisaris yang independen dapat secara efektif mengontrol mekanisme yang dilakukan oleh top manajer dalam perbedaan kepentingan dengan melakukan penunjukkan, pemecatan, dan penagihan denda kontrak kerja yang tepat atas prilaku pencitraan melalui kegiatan CSR oleh top manajer. Beberapa penelitian menyatakan bahwa kepemilikan institusional memiliki pengaruh yang signifikan dalam keputusan organisasi. Shleifer dan Vishny (1997) menyatakan bahwa kepemilikan institusional berpengaruh pada keputusan organisasi dengan adanya voting power yang dimilikinya sebagai pertentangan terhadap asimetri informasi oleh shareholders. Dengan 
menggunakan kekuatan dari informasi instiusional investor memiliki kecenderungan untuk lebih aktif terlibat dalam keputusan perusahaan dibandingkan pemegang saham non-institusional. Graves dan Waddock (1994) menemukan bahwa dampak dari kepemilikan institusional secara positif mendukung kegiatan CSR. Penelitian Hermanto (2013) dan Rice (2013), menemukan bahwa kepemilikan institusional memiliki proporsi yang cukup besar berpengaruh signifikan terhadap manajemen laba perusahaan yang terdaftar di di Bursa Efek Indonesia.

Perbedaan penelitian ini dengan penelitian terdahulu adalah ditambahkannya variabel pemoderasi, komisaris independen dalam mengurangi pengaruh antara manajemen laba dan pengungkapan CSR, penelitian ini juga menguji kepemilikan institusional sebagai variabel pemoderasi yaitu apakah faktor kepemilikan institusional dapat memperkuat hubungan negatif antara manajemen laba dan meningkatnya pengungkapan CSR. Perusahaan pertambangan adalah jenis industri yang sangat sensitif terhadap pencemaran lingkungan. Selain itu industri pertambangan termasuk dalam industri high profile yang memiliki visibilitas dari stakeholder, risiko politis yang tinggi, dan menghadapi persaingan yang tinggi. Industri high profile umumnya merupakan industri yang memperoleh sorotan dari masyarakat karena aktivitas operasinya memiliki potensi bersinggungan dengan kepentingan luas (stakeholder). Oleh karena itu, penelitian ini menggunakan perusahaan pertambangan sebagai objek penelitian, untuk menguji apakah variabel kepemilikan institusional dan komisaris independen dapat melemahkan keterkaitan antara corporate social responsibility dengan manajemen laba pada perusahaan pertambangan yang terdaftar di Bursa Efek Indonesia.

\section{Tinjauan Pustaka}

\subsection{Teori Keagenan (Agency Theory)}

Agent dan principal memiliki kepentingan yang berbeda, oleh karena itu akan menimbulkan konflik yang potensial. Sun et al.(2010) menjelaskan bahwa teori keagenan yang berkaitan dengan corporate governance dapat dijadikan alat manajer (agent) untuk meyakinkan investor (principal) dalam memastikan penerimaan return atas dana yang telah mereka investasikan. Menurut Gregory (2000) dewan komisaris merupakan inti dari corporate governance, dewan komisaris bertugas untuk memonitor dewan direksi terkait dengan pelaksanaan utama dewan direksi dalam menjalankan kegiatan perusahaan. Dewan komisaris bertindak untuk menyelaraskan pendapat agar tidak terjadi perselisihan antar manajer dan tentunya mengontrol pelaporan keuangan dan dipastikan tidak ada monopoli sehingga tidak menimbulkan manajemen laba. Demikian pula dengan kepemilikan institusional, yang dapat berperan sebagai pihak yang berpengaruh pada keputusan organisasi dengan adanya voting power yang dimilikinya sebagai pertentangan terhadap asimetri informasi oleh shareholders,Dengan 
menggunakan kekuatan dari informasi instiusional investor memiliki kecenderungan untuk lebih aktif terlibat dalam keputusan perusahaan dibandingkan pemegang saham non institusional.

\subsection{Signalling Theory}

Gray (2005) menyatakan bahwa kualitas dari pelaporan keuangan adalah sinyal bagi pasar keuangan dan stakeholder bahwa manajemen dianggap mampu untuk mengendalikan risiko sosial dan lingkungan dalam perusahaan. Pengungkapan kegiatan CSR adalah sinyal yang baik bagi investor dan stakeholder bahwa perusahaan aktif melakukan kegiatan CSR dan nilai pasar perusahaan berada dalam posisi yang baik. Kinerja sosial perusahaan yang baik membantu perusahaan untuk memperoleh reputasi dari pasar modal dan pasar utang. Pengungkapan CSR yang tinggi menunjukkan bahwa perusahaan memiliki komitmen yang tidakhanya fokus pada pencapaian keuangan saja tetapi juga perduli terhadap dampak yang ditimbulkan bagi karyawan, sosial dan lingkungan (Hong dan Andersen 2011).

\subsection{Penelitian Terdahulu dan Pembentukan Hipotesis}

Penelitian terdahulu terkait hubungan antara manajemen laba dan pengungkapan CSR telah cukup banyak diteliti, seperti penelitian oleh Kim et al.(2008); Hong dan Andersen (2011); Prioret al.(2008);Chih et al.(2008);Sun et al.(2010). Namun masih terdapat pertentangan hasil mengenai arah hubungan apakah manajemen laba berhubungan negatif atau berhubungan positif terhadap pengungkapan CSR, sebagian penelitian terdahulu menyatakan bahwa, manajemen laba dapat menjadi salah satu motif atau alasan bagi perusahaan untuk melakukan pengungkapan CSR. Sebaliknya, terdapat penelitian terdahulu yang menyatakan bahwa perusahaan yang mengungkapkan kegiatan CSR yang tinggi merupakan perusahaan yang etis dan cenderung tidak melakukan manajemen laba. Berdasarkan ketidakkonsistenan tersebut peneliti ingin menguji kembali hubungan antara manajemen laba dan pengungkapan CSR dengan mengambil perspektif CSR dari teori berbasis sosial-politis (socio-political theory) yang menyataakan keputusan bisnis dan hasilnya, termasuk dampak positif dan negatif yang tidak hanya dirasakan oleh perusahaan dan stakeholder tetapi juga masyarakat secara lebih luas, sehingga setiap keputusan yang diambil tidak hanya mempertimbangkan motivasi ekonomi saja, namun juga mempertimbangkan dampak sosial dan lingkungan yang diberikan terhadap stakeholder secara luas (Ferreira et al. 2010). Perbedaan dengan penelitian terdahulu adalah dengan memasukkan kepemilikan institusional sebagai faktor yang dapat memperkuat hubungan negatif antara manajemen laba dan meningkatnya pengungkapan CSR. Selain itu penelitian ini memasukkan peran dari komisaris independen dalam mengurangi pengaruh manajemen laba terhadap kegiatan CSR. 


\subsubsection{Manajemen Laba dan Tanggung Jawab Sosial Perusahaan}

Pengungkapan tanggung jawab sosial (CSR disclosure) merupakan salah satu pengungkapan yang dilakukan oleh perusahaan kepada pihak ketiga melalui laporan tahunan. Perusahaan mengadakan kegiatan tanggung jawab sosial karena perusahaan membutuhkan dukungan dari masyarakat lingkungan yang kondusif agar perusahaan dapat beroperasi dengan baik, dengan kata lain, perusahaan perlu legitimasi masyarakat sekitar. Kimet al.(2012), menyatakan bahwa kegiatan tanggung jawab sosial yang dilaporkan dalam laporan tahunan akan membuat informasi keuangan yang lebih handal bagi mereka yang menggunakan laporan keuangan tersebut. Perusahaan yang lebih banyak mengungkapkan informasi tentang kegiatan perusahaan akanmenjadi bentuk pengawasan yang lebih ketat untuk praktik manajemen laba. Sebaliknya, perusahaan yang kurang terbuka dalam kegiatan pengungkapan perusahaan cenderung untuk melakukan berbagai bentuk manajemen laba (Patten dan Trompeter 2003).

Posisi manajemen laba sebagai suatu tindakan yang melanggar etika terhadap pelaporan kinerja manajer berkebalikan dengan pelaporan kegiatan CSR yang menunjukkan bahwa perusahaan tersebut beretika dan memiliki komitmen untuk tidak hanya memberikan laporan keuangan yang baik namun juga memberikan transparansi yang tinggi dan kepedulian terhadap lingkungan. Mengakibatkan adanya hubungan negatif antara pengungkapan CSR yang dilakukan perusahaan dengan manajemen laba. Perusahaan yang memiliki pengungkapan tanggung jawab sosial yag tinggi akan membuat pelaporan keuangan menjadi transparan sehingga dapat mengurangi tindakan oportunistik manajer melalui manajemen laba.

Penelitian ini mengambil perspektif bahwa pengungkapan CSR dan manajemen laba memiliki hubungan negatif karena Shleifer (2004) menemukan bahwa manipulasi laba, yang merupakan tindakan melanggar etika cenderung tidak akan terjadi pada perusahaan yang memiliki komitmen yang tinggi untuk tanggungjawab sosial. Karena pengungkapan CSR mencerminkan transparansi dan menurunkan oportunistik manajemen laba. Gelb dan Strawser (2001) juga menemukan bahwa perusahaan yang melakukan tanggungjawab sosial menghasilkan informasi yang lebih banyak dibandingkan dengan perusahaan yang tidak berfokus pada kegiatan dan pengungkapan CSR. Chih et al. (2008) menunjukkan bahwa transparansi yang lebih baik dalam pengungkapan akuntansi dapat menurunkan incentive manajer dalam melakukan manajemen laba, hal tersebut disebabkan karena perusahaan tidak hanya berfokus pada laba yang dilaporkan tetapi juga berfokus terhadap hubungan masa depan dengan lingkungan dan stakeholder. Berdasarkan uraian tersebut, maka hipotesis yang diajukan adalah:

\section{H1: Pengungkapan tanggung jawab sosial perusahaan berhubungan negatif dengan manajemen laba.}




\subsubsection{Manajemen Laba, Corporate Social Responsibility dan Komisaris Independen}

Komisaris independen dapat bertindak sebagai penengah dalam perselisihan yang terjadi diantara para manajer internal dan mengawasi kebijakan manajemen serta memberikan nasihat kepada manajemen. Komisaris independen merupakan posisi terbaik untuk melaksanakan fungsi monitoring agar tercipta perusahaan yang good corporate governance. Komisaris independen akan menjalankan proses monitoring yang lebih efektif terkait manajemen laba. Hal tersebut menunjukkan bahwa dewan komisaris yang independen memiliki kecenderungan untuk menghalangi manajer untuk melakukan manajemen laba, sehingga kualitas laba yang dilaporkan menjadi lebih tinggi.

Jo dan Harjoto (2011) menemukan bahwa persentase komisaris independen memiliki tingkat signifikansi dan hubungan positif terkait dengan keputusan perusahaan mengenai kegiatan CSR. Fama dan Jensen (1983) menyatakan bahwa dewan komisaris yang independen dapat secara efektif mengontrol mekanisme yang dilakukan oleh top manajer dalam perbedaan kepentingan dengan melakukan penunjukan, pemecatan, dan denda yang tepat atas perilaku pencitraan melalui kegiatan CSR oleh top manajer. Berdasarkan pemaparan di atas, hipotesis yang dikembangkan adalah:

\section{H2: Komisaris independen dapat memperkuat hubungan negatif antara manajemen laba dengan pengungkapan corporate social responsibility.}

\subsubsection{Manajemen Laba, Corporate Social Responsibility dan Kepemilikan Institusional}

Kepemilikan Institusional memiliki kemampuan untuk mengurangi insentif para manajer yang mementingkan diri sendiri melalui tingkat pengawasan yang intens. Kepemilikan institusional dapat menekan kecenderungan manajemen untuk memanfaatkan discretionary dalam laporan keuangan sehingga memberikan kualitas laba yang lebih tinggi. Kepemilikan institusional memiliki kemampuan untuk mengendalikan pihak manajemen melalui proses monitoring secara efektif sehingga mengurangi tindakan manajemen melakukan manajemen laba. Selain komisaris independen kepemilikan institusional juga diduga dapat menjadi faktor yang bisa menurunkan hubungan antara kegiatan CSR dengan manajemen laba yang dilakukan oleh manajer. Shleifer dan Vishny menemukan bahwa (1997) kepemilikan institusional berpengaruh pada keputusan organisasi dengan adanya voting power yang dimilikinya sebagai pertentangan terhadap asimetri informasi oleh shareholders. Dengan menggunakan kekuatan dari informasi institusional investor memiliki kecenderungan untuk lebih aktif terlibat dalam keputusan perusahaan dibandingkan pemegang saham non-institusional.

Graves dan Waddock (1994) menemukan bahwa dampak dari kepemilikan institusional secara positif mendukung kegiatan CSR. Cornett (2006) menemukan bahwa tindakan 
pengawasan perusahaan oleh pihak investor institusional dapat mendorong manajer untuk lebih memfokuskan perhatiannya terhadap kinerja perusahaan sehingga akan mengurangi perilaku oportunistik atau mementingkan diri sendiri. Berdasarkan literatur di atas, hipotesis yang dikembangkan adalah:

H3: Kepemilikan institusional dapat memperkuat hubungan negatif antara manajemen laba dengan pengungkapan corporate social responsibility

\subsection{Model Penelitian}

Gambar 2.1

Model Penelitian

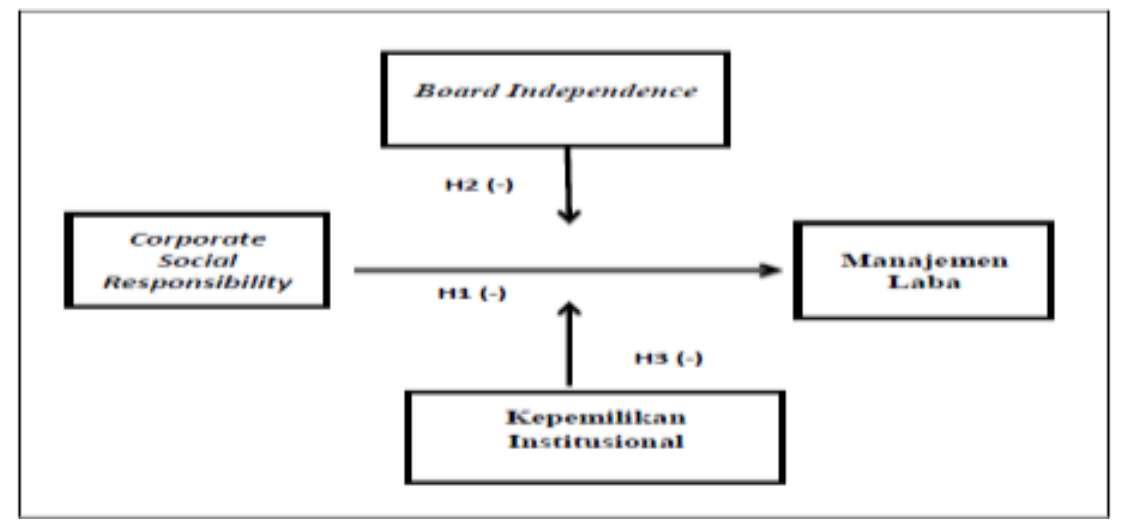

\section{Metodologi Penelitian}

Penelitian ini menggunakan data sekunder yang diperoleh melalui website OSIRIS dan Bursa Efek Indonesia (www.idx.co.id) untuk laporan keuangan data dan laporan tahunan. Sampel dalam penelitian ini adalah perusahaan pertambangan yang tercatat di BEI dengan periode penelitian 5 tahun, dari 2010-2014. Alasan memilih periode tersebut karena tahun 2010-2014 merupakan 5 tahun terakhir ketika penelitian ini dilakukan, sehingga dapat melihat perkembangan terakhir atas pengungkapan CSR pada perusahaan pertambangan yang terdaftar di bursa efek Indonesia. Penelitian inimenggunakanmetode purposive samplingdalam pemilihan sampel.

\subsection{Definisi Variabel Operasional}

Penelitian ini menguji variabel dependen (manajemen laba akrual). Variabel independen (CSR). Variabel moderasi (komisaris independen dan kepemilikan institusional). Variabel kontrol yaitu ukuran perusahaan dan profitabilitas, variable kontrol tersebut dipilih karena telah konsiten terbukti berpengaruh terhadap manajemen laba sebagai variable dependen. Setiap variabel dijelaskan di bawah ini: 


\subsubsection{Manajemen Laba Akrual Sebagai Variabel Dependen}

Manajemen laba menggunakan proksi discretionary accrual, diukur menggunakan modified Jones model,karena model ini merupakan pemuktahiran model Jones sebelumnya oleh Dechow et al. (1995) yang memperbaiki kelemahan model Jones dengan mengurangkan variabel perubahan piutang dari variabel perubahan pendapatan untuk pengestimasian akrual nondiskresioner di saat periode kejadian. Model tersebutmemisahkan discretionary accruals dan non discretionary accruals serta mengurangi asumsi bahwa komponen nondiscretionary accruals adalah konstan. Selengkapnya tahap-tahap penentuan manajemen laba akrual adalah seperti berikut:

\section{(1) Menghitung total akrual:}

$$
\mathrm{TAC}_{\text {it }}=\mathrm{NI}_{\mathrm{it}}-\mathrm{CFO}_{\mathrm{it}}
$$

(2) Menentukan koefisien dari regresi total akrual:

$\mathrm{TAC}_{\mathrm{it}} / \mathrm{A}_{\mathrm{it}-1}=\beta 1\left(1 / \mathrm{A}_{\mathrm{it}-1}\right)+\beta 2\left(\left(\Delta R E V_{\mathrm{it}} / \mathrm{A}_{\mathrm{it}-1}\right)+\beta 3\left(P P E_{i t} / \mathrm{A}_{\mathrm{it}-1}\right)+\varepsilon_{\mathrm{it}}\right.$

(3) Menghitung Nondiscretionary Accruals (NDAC)

$$
\operatorname{NDAC}_{i t}=\alpha_{1}\left(1 / A_{i t-1}\right)+\alpha_{2}\left(\Delta \operatorname{REV}_{i t} / A_{i t-1}-\Delta R E C_{t} / A_{i t-1}\right)+\alpha_{3}\left(P E_{i t} / A_{i t-1}\right)
$$

(4) Menentukan Discretionary Accrual

DAC $=\left(T A C / A_{i t-1}\right)-$ NDAC

\section{Keterangan:}

$\mathrm{DAC}_{\text {it }}=$ Discretionary Accruals perusahaan i pada tahun ke $\mathrm{t}$

NDA $_{\text {it }} \quad=$ Nondiscretionary accruals perusahaan i pada periode ke $\mathrm{t}$

$\mathrm{TAC}_{\text {it }} \quad=$ Total accruals perusahaan i pada tahun $\mathrm{t}$

$\mathrm{N}_{\mathrm{it}} \quad=$ Laba bersih perusahaan i pada periode ke $\mathrm{t}$

$\mathrm{A}_{\mathrm{it}-1}=$ Total aset perusahaan i pada akhir tahun $\mathrm{t}-1$

$\triangle \mathrm{REV}_{\text {it }} \quad=$ Perubahan pendapatan perusahaan $\mathrm{i}$ pada tahun $\mathrm{t}$ dikurangi pendapatan tahun $\mathrm{t}-1$

$\triangle \mathrm{REC}_{\mathrm{i}} \quad=$ Perubahan piutang bersih perusahaan i pada tahun $\mathrm{t}$ dikurangi piutang bersih tahun $\mathrm{t}-1$

PPEit = Gross property, plant and equipment perusahaan i pada tahun $\mathrm{t}$

Discretionary accrual dalam penelitian ini dihitung secara time series dan DAC diabsolutkan, karena dalam penelitian ini tidak menguji motivasi manajemen laba seperti income icreasing atau income decreasing.

\subsubsection{Tanggung Jawab Sosial Perusahaan}

Penelitian ini menggunakan Instrumen CSRI mengacu pada instrumen Global Reporting Initiative (GRI) G.4. GRI adalah organisasi berbasis jaringan yang telah mempelopori pengembangan laporan keberlanjutan di dunia yang paling banyak digunakan dan berkomitmen untuk perbaikan terus-menerus. GRIversi 4 digunakan dalam penelitian ini, karena merupakan indeks item pengungkapan yang lebih luas dan lebih lengkap, yang berisi item-item 
pengungkapan dari CSRI GRI versi terdahulu, ditambah dengan 14 item pengungkapan CSR. Informasi kegiatan CSR dikelompokkan menjadi tiga kategori, yaitu: ekonomi, kinerja lingkungan, sosial, kategori sosial dibagi menjadi empat sub-kategori, yaitu: praktik ketenagakerjaan dan pekerjaan yang layak, hak asasi manusia, masyarakat dan tanggung jawab produk. Kategori dibagi menjadi 91 item dengan rincian sebagai berikut:

a. kategori ekonomi, terdiri dari 4 aspek dan 9 indikator.

b. kategori lingkungan, yang terdiri dari 12 aspek dan 34 indikator

c. kategori sosial, terdiri dari empat sub-kategori, 30 aspek dan 48 indikator.

Pengukuran CSRI dilakukan melalui analisis konten dalam mengukur berbagai CSRI. Pendekatan ini pada dasarnya menggunakan pendekatan dikotomis, yaitu masing-masing kategori pengungkapan informasi CSR dalam instrumen penelitian diberi skor 1 jika diungkapkan dalam laporan tahunan, dan nilai 0 jika informasi kategori tidak diungkapkan dalam laporan tahunan. Selanjutnya, skor ditambahkan untuk mendapatkan skor keseluruhan untuk setiap perusahaan. Pengukuran dengan menggunakan rumus berikut:

$$
\text { CSRI }=\frac{\text { Total item yang diungkapkan perusahaan }}{\text { Total Item Pengungkapan }}
$$

\subsubsection{Variabel Pemoderasi}

\subsubsection{Kepemilikan Institusional}

Kepemilikan institusional adalah kepemilikan saham oleh institusi berbadan hukum, institusi keuangan, institusi luar negeri, dana perwalian serta institusi lainnya. Dalam struktur kepemilikan institusional pengukuran variabel ini menggunakan proporsi kepemilikan saham institusional, yaitu rasio antara kepemilikan saham institusional terhadap total saham beredar (Young et al.2011).

Kepemilikan $=$ Kepemilikan Saham Institusional $\times 100$ Institusional Total Saham Beredar

\subsubsection{Komisaris Independen}

Board Independence atau dewan komisaris yang independen diukur dengan PINED (Proportion Independent Director) pada dewan perusahaan. Dewan komisaris dikatakan independent jika mereka tidak memiliki hubungan dengan perusahaan dan tidak memiliki transaksi dengan pihak-pihak terkait dengan perusahaan (Jaggi et al.2009). 


$$
\begin{gathered}
\text { Dewan Komisaris } \\
\text { Independen }
\end{gathered}=\frac{\text { Komisaris Independen }}{\text { Jumlah Dewan Komisaris }} \times 100
$$

\subsubsection{Variabel Kontrol}

\subsubsection{Ukuran Perusahaan (SIZE)}

Berdasarkan penelitian Sun et al. (2010) dan Prior et al. (2008), semakin besar ukuran perusahaan maka semakin tinggi pengungkapan CSR perusahaan. Ukuran perusahaan diprediksi berhubungan positif dengan CSR. Ukuran perusahaan yang diukur denganlog asset.

\subsubsection{Profitabilitas (EBIT it)}

Semakin tinggi profitabilitas perusahaan, maka akan semakin besar pula kemungkinan perusahaan meningkatkan CSR. Penelitian sebelumnya menunjukkan bahwa profitabilitas perusahaan memiliki hubungan positif dengan pengungkapan CSR (Sun et al. 2010).

\section{$\mathrm{EBIT}=\quad$ Laba sebelum bunga dan pajak}

Total Aset

\section{Pengujian Hipotesis}

Pengujian hipotesis dalam penelitian ini menggunakan model persamaan sebagai berikut:

\section{Model Hipotesis 1}

$\mathrm{EM}_{\mathrm{it}}=\alpha_{0}+\alpha_{1} \mathrm{CSR}_{\mathrm{it}}+\alpha_{2} \mathrm{SIZE}_{\mathrm{it}}+\alpha_{4} \mathrm{EBIT}_{\mathrm{it}}+€_{\mathrm{it}}$

\section{Model Hipotesis 2}

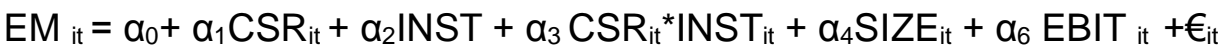

\section{Model Hipotesis 3}

$\mathrm{EM}_{\mathrm{it}}=\alpha_{0}+\alpha_{1} \mathrm{CSR}_{\mathrm{it}}+\alpha_{2}$ PINED $+\alpha_{3}$ CSR $_{\mathrm{it}}{ }^{*}$ PINED $_{\mathrm{it}}+\alpha_{4}$ SIZE $_{\mathrm{it}}+\alpha_{6} \mathrm{EBIT}_{\mathrm{it}}+\epsilon_{\mathrm{it}}$

\section{Keterangan:}

$\begin{array}{ll}\text { EM } & =\text { Earnings Manajement } \\ \text { CSR } & =\text { Corporate Sosial Responsibility } \\ \text { PINED } & =\text { Dewan Komisaris Independen (Board Independence) } \\ \text { INST } & =\text { Kepemilikan Institusional } \\ \text { SIZE } & =\text { Ukuran Perusahaan } \\ \text { EBIT } & =\text { Profitabilitas }\end{array}$




\section{Analisis dan Pembahasan}

\subsection{Pengumpulan Data}

Populasi dalam penelitian ini adalah perusahaan pertambangan yang tercatat di BursaEfek Indonesia, sesuai dengan kriteriayang ditetapkan dalam penelitian ini, dengan 5 tahun periode penelitian yaitu tahun 2010-2014.

Tabel 4.1

Proses Pemilihan Sampel Perusahaan

\begin{tabular}{|l|l|c|}
\hline \multicolumn{1}{|c|}{ Ko Kriteria } & \multicolumn{1}{|c|}{$\begin{array}{c}\text { Jumlah } \\
\text { Perusahaan- } \\
\text { tahun }\end{array}$} \\
\hline 1 & $\begin{array}{l}\text { Perusahaan pertambangan yang terdaftar di BEI } \\
38\end{array}$ \\
\hline 2 & $\begin{array}{l}\text { Perusahaan pertambangan yang tidak konsisten menerbitkan } \\
\text { laporan tahunan dan laporan keuangan selama periode } \\
\text { penelitian }\end{array}$ & $(14)$ \\
\hline 3. & $\begin{array}{l}\text { Perusahaan yang tidak memiliki data lengkap terkait variabel } \\
\text { penelitian yang dibutuhkan }\end{array}$ & $(1)$ \\
\hline & Jumlah Sampel yang digunakan & $\mathbf{2 3}$ \\
\hline & Periode penelitian (tahun) & $\mathbf{5}$ \\
\hline & Total perusahaan selama 5 tahun & $\mathbf{1 1 5}$ \\
\hline & Jumlah observasi yang outlier & $\mathbf{2 5}$ \\
\hline & Jumlah akhir observasi penelitian & $\mathbf{9 0}$ \\
\hline
\end{tabular}

Sumber: data olahan sendiri

Dari tabel 4.1 di atas diperoleh sampel dengan kriteria yang telah ditentukan, sebanyak 23 perusahaan pertambangan, dengan menggunakan metode pooling data atau kombinasi dari data time series dan data cross section pada periode tahun 2010-2014, ada 25 pengamatan outlier dan dikeluarkan dalam data pengolahan, sehingga diperoleh sampel (n) akhir sejumlah 90 perusahaan-tahun.

\subsection{Statistik Deskriptif}

Berdasarkan perhitungan statistik, maka data penelitian pada perusahaan pertambangan di Bursa Efek Indonesia periode 2010-2014 dapat dijelaskan pada tabel 4.2 berikut ini:

Tabel 4.2

Statistik Deskriptif

\begin{tabular}{|l|l|l|l|l|}
\hline Variabel & \multicolumn{1}{l}{ Min } & Max & \multicolumn{1}{l|}{ Mean } & \multicolumn{1}{l|}{ Std. Dev } \\
\hline EM & 0,0055 & 2,0330 & 0,3503 & 0,3847 \\
\hline CSR & 0,1870 & 0,4500 & 0,2732 & 0,0989 \\
\hline INST & 0,31750 & 0,96850 & 0,69329 & 0,17809 \\
\hline PINED & 30 & 50 & 38,16 & 6,68 \\
\hline SIZE & 2,8417 & 8,0257 & 6,4691 & 1,2095 \\
\hline EBIT & $-0,1365$ & 0,5160 & 0,1521 & 0,1278 \\
\hline
\end{tabular}

Sumber: data olahan SPSS 
Variabel pertama ditunjukkan pada Tabel 4.2 adalah variabel dependen manajemen laba (EM). Nilai minimum 0,0055 menunjukkan tingkat terkecil akrual yang tidak normal yang merupakan tingkat akrual hasil rekayasa laba yang dilakukan oleh manajer, sedangkan nilai maksimum adalah 2,0330. Rata-rata hasil statistik deskriptif menunjukkan bahwa tingkat akrual yang tidak normal cukup besar yaitu 0,3503.

Variabel kedua adalah CSR yang merupakan variabel independen dalam penelitian ini mengukur luasnya pengungkapan CSR dalam laporan tahunan yang disajikan perusahaan. Nilai minimum dari CSR adalah 0,187 menunjukkan kecilnya kontribusi atau pengungkapan yang dilakukan perusahaan terhadap CSR (item pengungkapan berdasarkan GRI G.4), sedangkan nilai maksimum adalah 0,45 menunjukkan kontribusi perusahaan terhadap CSR. Rata-rata hasil statistik deskriptif menunjukkan bahwa kontribusi perusahaan terhadap pengungkapan kegiatan CSR cukup kecil yaitu hanya 0,273 atau rata-rata perusahaan hanya mengungkapkan item CSR sebesar $27 \%$ dari pengungkapan CSR yang disyaratkan oleh GRI G.4.

Variabel ketiga yaitu kepemilikan institusional yang diukur dari jumlah saham yang dimiliki oleh institusi berbadan hukum, institusi keuangan, institusi luar negeri, dana perwalian serta institusi lainnya dibandingkan dengan keseluruhan saham yang beredar.sebagai variabel pemoderasi (INST) dengan nilai minimum yaitu 0,3175 dan nilai maksimum 0,9685 dan ratarata perusahaan pertambangan sebagai sampel memiiki persentase kepemilikan saham oleh institusi lain sebesar 0,6933 dari keseluruhan saham perusahaan. Variabel keempat yaitu dewan komisaris independen sebagai variabel pemoderasi, hasil pengujian statistik deskriptif menunjukkan nilai minimum sebesar $30 \%$, nilai maksimum $50 \%$, dan nilai rata-rata persentase dewan komisaris independen adalah sebesar 38,16\% nilai tersebut tidak menunjukkan rentang yang terlalu signifikan antara nilai minimum dan maksimum, nilai tersebut juga sesuai dengan peraturan yang mengharuskan setiap perusahaan memiliki minimal 30\% komisaris independen dalam suatu perusahaan.

Variabel kelima adalah (SIZE) merupakan variabel kontrol dalam penelitian ini. Nilai minimum dari (SIZE) sebesar 2,8417 menunjukkan kategori ukuran perusahaan adalah kecil sedangkan nilai maksimum sebesar 8,0257 menunjukkan bahwa kategori ukuran perusahaan besar. Rata-rata hasil statistik deskriptif adalah 6,4691 menunjukkan bahwa perusahaan dalam penelitian ini termaksud dalam kategori besar. Variabel keenam dalam penelitian ini adalah EBIT sebagai variabel kontrol yang menunjukkan tingkat profitabilitas yang mampu dihasilkan oleh perusahaan, dengan nilai minimum sebesar yaitu -0,1365 atau perusahaan gagal menghasilkan profitabilitas (rugi), dan nilai maksimum sebesar 0,5160 dapat dikategorikan perusahaan yang berhasil menunjukkan profitabilitas yang cukup tinggi, sedangkan rata-rata profitabilitas yang dihasilkan perusahaan sebagai sampel dalam penelitian ini adalah sebesar 0,1521 . 


\subsection{Uji Asumsi Klasik}

Hasil uji K-S menunjukkan bahwa seluruh residual pada model regresi berdistribusi normal. Hal ini ditunjukkan dengan nilai Asymp. Sig. (2-tailed) pada masing-masing model lebih besar dari 0,05 (Model 1: 0,61 model 2:0,17; model 3: 0,29). Sehingga dapat disimpulkan bahwa seluruh model regresi tidak memiliki masalah normalitas. Hasil uji multikolinearitas menunjukkan bahwa tidak ada satu variabel independen yang memiliki nilai VIF sama dengan atau lebih kecil dari 10 ataupun nilai tolerance yang sama dengan atau lebih besar dari 0,10 . Hal ini menunjukkan bahwa tidak terdapat gejala multikolinearitas.

Pengujian asumsi klasik autokorelasi dilakukan dengan pendekatan Durbin Watson (DW). Menunjukkan bahwa nilai statistik DW pada model 1 berada diantara nilai du dan 4-du yang mengindikasikan bahwa tidak terdapat autokorelasi. Hasil perhitungan tidak ditemukan variabel independen yang secara signifikan mempengaruhi nilai absolut residual. Hal ini menunjukkan bahwa pada model penelitian tidak terdapat ketidaksamaan variance dari residual satu pengamatan dengan varianceresidual pengamatan lain.

\subsection{Pengujian Hipotesis}

Dengan terpenuhinya semua syarat asumsi klasik maka dapat dilakukan uji hipotesis. Uji hipotesis ini dilakukan untuk mengetahui hubungan antara manajemen laba (EM) terhadap CSR sebagai variabel independen dan dewan komisaris independen (PINED) serta kepemilikan institusional (INST) sebagai variabel pemoderasi. Pada uji ini juga terdapat dua variabel kontrol yaitu ukuran perusahaan (SIZE) dan profitbilitas (EBIT). Hasil dari analisis regresi disajikan pada tabel 4.7 sebagai berikut:

Tabel 4.7

Analisis Regresi

\begin{tabular}{|l|l|l|l|l|l|l|l|}
\hline $\begin{array}{l}\text { Variabel } \\
\text { Independen }\end{array}$ & \multirow{2}{*}{$\begin{array}{l}\text { Tanda } \\
\text { Prediksian }\end{array}$} & $\begin{array}{l}\text { Model 1 } \\
\text { Koefesien } \\
\text { (p-value) }\end{array}$ & Sig. & $\begin{array}{l}\text { Koefesien } \\
\text { (p-value) }\end{array}$ & Sig. & $\begin{array}{l}\text { Koefesien } \\
\text { (p-value) }\end{array}$ & Sig. \\
\hline Constant & $?$ & 0,116 & 0,673 & 0,508 & 0,258 & 0,842 & 0,031 \\
\hline CSR & - & $-0,527$ & 0,013 & 1,012 & 0,081 & 0,975 & 0,040 \\
\hline Size & + & $-0,019$ & 0,568 & -0.035 & 0,269 & $-0,026$ & 0,408 \\
\hline EBIT & + & 0,271 & 0,405 & 0,282 & 0,350 & 0,310 & 0,311 \\
\hline PINED & - & & & 0,038 & 0,000 & & \\
\hline CSR_PINED & - & & & $-0,079$ & 0,011 & & \\
\hline INST & & & & & & 0,015 & 0,00 \\
\hline INST_CSR & & & & & & $-0,044$ & 0,00 \\
\hline N & & & & 90 & & 90 & 1 \\
\hline $\mathbf{R}^{2}$ & & 90 & & 0,231 & & 0,215 & \\
\hline Adj R2 & & 0,077 & 0,186 & & 0,169 & \\
\hline F Value & & 0,045 & 5,059 & & 4,615 & \\
\hline
\end{tabular}

Sumber: data olahan SPSS 
Hasil regresi pada model 1 menunjukkan nilai signifikansi untuk persamaan regresi tanpa interaksi (main effect model), bertujuan untuk menganalisis hubungan antara variabel dependen (CSR) dengan variabel independen (EM). Tabel 4.7 menunjukkan bahwa variabel CSR memberikan pengaruh negatif yang ditunjukkan dari nilai koefesien yang bernilai negatif (0,527) dan signifikansi $(0,013)$ dibawah level signifikansi $5 \%$. Perolehan ini menunjukkan adanya pengaruh signifikan negatif yang diberikan CSR sebagai variabel independen ke EM sebagai variabel dependen sesuai dengan $\mathrm{H} 1$ sehingga dapat disimpulkan bahwa $\mathbf{H 1}$ terdukung.

Hasil regresi pada model 2 menunjukkan nilai signifikansi untuk persamaan regresi dengan interaksi (interaction effect model), bertujuan untuk menguji pengaruh antara CSR sebagai variabel independen dan variabel dewan komisaris independen (PINED) sebagai pemoderasi terhadap manajemen laba (EM) sebagai variabel dependen. Tabel 4.7 menunjukkan bahwa interaksi dari variabel PINED dapat memperkuat hubungan negatif antara CSR dan EM yang ditunjukkan dari nilai koefesien $(-0,079)$, dan juga menunjukkan adanya keterkaitan yang signifikan dengan nilai 0,011 , dibawah signifikansi pada level $5 \%$. Hasil tersebut sesuai dengan hipotesis 2 yang menyatakan bahwa dewan komisaris independen (PINED) dapat memperkuat hubungan negatif antara CSR dan EM, sehingga dapat disimpulkan bahwa $\mathbf{H 2}$ terdukung.

Hasil regresi pada model 3 menunjukkan nilai signifikansi untuk persamaan regresi dengan interaksi (interaction effect model), bertujuan untuk menguji pengaruh antara CSR sebagai variabel independen dan variabel kepemilikan institusional sebagai pemoderasi terhadap manajemen laba (EM) sebagai variabel dependen. Tabel 4.7 menunjukkan bahwa interaksi dari variabel INST dapat memperkuat hubungan negatif antara CSR dan EM yang ditunjukkan dari nilai koefesien $(-0,044)$, dan juga menunjukkan adanya keterkaitan yang signifikan dengan nilai 0,001, dibawah signifikansi pada level $5 \%$. Hasil tersebut sesuai dengan hipotesis 3 yang menyatakan bahwa dewan kepemilikan istitusional (INST) dapat memperkuat hubungan negatif antara CSR dan EM, sehingga dapat disimpulkan bahwa H3 terdukung.

\subsection{Temuan Penelitian}

\subsubsection{Manajemen Laba dan Corporate Social Responsibility}

Hasil penelitian ini membuktikan bahwa terdapat hubungan negatif yang kuat antara CSR dan manajemen laba. Perusahaan yang beretika dan peduli terhadap tanggungjawab sosial akan memiliki pengungkapan CSR yang tinggi dan cenderung untuk melaporkan kinerja keuangan dengan lebih transparan dan menunjukkan manajemen laba yang rendah, mengindikasikan laporan kinerja perusahaan yang dapat dipercaya. Hasil penelitian ini sejalan dengan penelitian terdahulu oleh Hong dan Andersen (2011). 
Penelitian ini mendukung teori signaling yang menjelaskan bahwa manajer memberian sinyal positif melalui pengungkapan CSR yang tinggi dengan tujuan untuk mengurangi asimetri informasi. Manajer memberikan informasi CSR yang lebih luas kepada sharehorder karena ingin memberikan ruang bagi investor untuk mengetahui bagaimana keputusan yang akan diambilnya berkaitan dengan nilai perusahaan tersebut, berdasarkan kinerja perusahaan yang diungkapkan dengan lebih transparan. Pengungkapan CSR merupakan pengungkapan yang memberikan sinyal bahwa perusahaan mempunyai prospek yang baik di masa mendatang (good news) sehingga investor tertarik untuk melakukan perdagangan saham, dengan demikian pasar akan bereaksi yang tercermin melalui perubahan dalam volume perdagangan saham.

Hasil penelitian ini juga mendukung socio-political theory. Perusahaan yang menyadari perlunya legitimasi dari masyarakat sekitarnya atau membutuhkan dukungan dari lingkungan masyarakat yang kondusif agar perusahaan dapat beroperasi dengan baik akan melakukan kegiatan pertanggungjawaban kepada lingkungan dan sosial seperti; pelestarian lingkungan, pembangunan sarana prasarana publik dan peningkatan kesejahteraan karyawan dll. Kesadaran akan legitimasi masyarakat akan mendorong perusahaan untuk mengungkapkan informasi mengenai aktivitas CSR perusahaan sehingga membatasi praktik manajemen laba, sebaliknya perusahaan yang kurang terbuka dalam pengungkapan informasi kegiatan perusahaan dapat terdorong untuk melakukan berbagai bentuk manajemen laba baik untuk keuntungan pribadi maupun keuntungan perusahaan, dengan melakukan tindakan oportunistik yang bertujuan untuk mencari keuntungan sepihak, hasil penelitian sesuai dengan penelitian Patten dan Trompter (2003).

Hasil penelitian ini juga mendukung penelitian Shleifer (2004) yang menemukan bahwa manipulasi laba yang merupakan tindakan yang melanggar etika cenderung tidak akan terjadi pada perusahaan yang memiliki komitmen yang tinggi untuk tanggungjawab sosial. Perusahaan yang berkomitmen untuk bertanggungjawab sosial akan bersedia untuk mengalokasikan dana yang cukup besar dari laba yang dihasilkan perusahaan untuk kegiatan sosial dan lingkungan, cenderung tidak akan melakukan tindakan manajemen laba yang justru dapat merusak komitmen yang telah dibangun sebelumnya. Hal ini disebabkan karena pengungkapan CSR mencerminkan transparansi dan menurunkan oportunistik manajemen laba selain itu juga disebabkan karena perusahaan tersebut tidak hanya berfokus pada laba yang dilaporkan tetapi juga berfokus terhadap hubungan masa depan dengan lingkungan dan stakeholder. Hasil penelitian ini dapat bermanfaat sebagai sebuah pertimbangan dalam keputusan investasi bagi investor, yaitu pentingnya mempertimbangkan aspek pengungkapan khususnya pengungkapan CSR yang mengindikasikan transparansi dalam pelaporan kinerja perusahaan dan mencerminkan rendahnya manipulasi laba. Sehingga menunjukkan perusahaan yang memiliki prospek yang baik di masa mendatang (good news). 


\subsubsection{Manajemen Laba, Corporate Social Responsibility dan Dewan Komisaris Independen}

Hasil penelitian ini telah menemukan bahwa dewan komisaris independen dapat memperkuat hubungan negatif antara pengungkapan CSR dengan manajemen laba. Komisaris independen dapat mendorong terciptanya iklim yang lebih objektif diantara berbagai kepentingan, termasuk kepentingan perusahaan dan kepentingan stakholder sebagai prinsip utama dalam pengambilan keputusan oleh dewan komisaris. Hasil penelitian mendukung penelitian Jaggi et al.(2009) yang menemukan bahwa komisaris independen berfungsi mengawasi pengelolaan perusahaan yang dilaksanakan oleh manajemen. Dewan komisaris independen memberikan pengaruh yang kuat untuk menekan manajer mengungkapkan CSR, dalam kaitannya dengan manajemen dewan komisaris independent bertanggungjawab untuk menjamin transparansi, keterbukaan dan keluasan pengungkapan laporan keuangan perusahaan sehingga akan menjalankan proses monitoring yang efektif untuk memastikan manajer tidak melakukan tindakan yang menguntungkan dirinya secara sepihak. Dewan komisaris independen dapat mengurangi risiko yang timbul akibat perbedaan kepentingan antara agen dan principal seperti yang dijelaskan dalam agency theory. Selain itu komisaris independen juga diangkat dalam suatu perusahaan karena memiliki keahlian, keterampilan dan keilmuan yang dianggap mampu untuk menjalankan proses monitoring seperti, latar belakang keahlian akuntansi dan bisnis.keahlian tersebut dapat efektif untuk menghalangi tindakan oportunistik manajer seperti tindakan manajemen laba, sehingga kualitas laba yang dilaporkan menjadi lebih tinggi.

Hasil penelitian ini sejalan dengan peneitian oleh Jo dan Harjoto (2011). Dewan komisaris yang independen dapat secara efektif mengontrol mekanisme yang dilakukan oleh top manajer dalam perbedaan kepentingan dengan melakukan penunjukan, pemecatan dan denda yang tepat atas perilaku oportuistik yang dilakukan oleh manajer. Selain itu komisaris independen dapat bertindak sebagai penengah dalam perselisihan atau dalam benturan kepentingan yang terjadi diantara manajer internal dan mengawasi kebijakan serta memberikan nasihat kepada manajemen sehingga manajer didorong untuk lebih memberikan laporan kinerja yang transparan salahsatunya dengan pengungkapan kegiatan CSR dan menuntut manajer untuk memberikan laporan keuangan yang lebih akurat atau menghalangi tindakan manipulasi atau manajemen laba.

\subsubsection{Manajemen Laba, Corporate Social Responsibility dan Kepemilikan Institusional}

Hasil penelitian ini menunjukkan bahwa kepemilikan institusional dapat memperkuat hubungan negatif antara pengungkapan CSR dengan manajemen laba. Kepemilikan saham oleh institusi lain memiliki kemampuan untuk mengurangi insentif manajer yang mementingkan diri sendiri melalui pengawasan yang intens. Pengawasan tersebut dapat mengurangi tindakan 
manajer yang memanfaatkan fleksibilitas pemilihan metode akuntansi yang bertujuan untuk mencapai laba yang diinginkan, hasil penelitian ini sejalan dengan Shleifer dan Vishny (1997). Kepemilikan institusional berpengaruh pada keputusan organisasi dengan adanya voting power yang dimilikinya sebagai pertentangan terhadap asimetri informasi oleh shareholder. Voting power yang dimiliki oleh kepemilikan institusional dapat mengurangi adanya kesempatan manajer yang berperilaku oportunistik. Dengan proporsi kepemilikan institusi yang tinggi memungkinkan adanya keterlibatan institusi lain dalam keputusan perusahaan dibandingkan kepemilikan non-institusional. Penelitian ini juga membuktikan bahwa kepemilikan institusional dapat mendukung kegiatan CSR, karena institusi lain akan mendorong adanya pengungkapan yang lebih luas sebagai suatu bentuk peningkatan transparansi dalam pelaporan kinerja perusahaan dan mencerminkan kinerja perusahaan yang dapat diandalkan, hasil tersebut mendukung penelitian Graves dan Waddock (1994).

\section{Kesimpulan, Keterbatasan, dan Saran}

\subsection{Kesimpulan}

Hasil penelitian ini menunjukkan bahwa terdapat pengaruh negatif antara tingginya pengungkapan CSR yang dilakukan perusahaan pertambangan di Indonesia dengan prilaku manajemen laba yang dilakukan oleh manajer. Temuan ini menunjukkan bahwa perusahaan yang memutuskan untuk melaporkan kegiatan CSR yang tinggi mencerminkan pengungkapan yang lebih lua, transparansi dan lebih baik, hal ini akan mengurangi oportunistik manajer untuk melakukan manajemen laba. Pengungkapan CSR mencerminkan perusahaan yang beretika dan berkomitmen memenuhi harapan etis stakholder dengan berupaya untuk berkontribusi terhadap lingkungannya sehingga cenderung tidak melakukan manajemen laba akrual yang justru dapat merusak kepercayaan stakeholder terhadap perusahaan.

Tujuan kedua penelitian ini adalah untuk menguji pengaruh pengungkapan kegiatan CSR terhadap manajemen laba dengan mempertimbangkan presentase dewan komisaris independen. Hasil analisis menunjukan bahwa terdapat efek interaksi pengungkapan CSR dan dewan komisaris independen pada hubungan antara pengungkapan CSR terhadap manajemen laba. Dengan demikian, hipotesis kedua yang menyatakan bahwa dengan adanya presentase dewan komisaris independen yang tinggi dapat memperkuat hubungan negatif antara pengungkapan CSR dan manajemen laba terdukung secara statistik. Berdasarkan hasil penelitian ini dapat disimpulkan bahwa komisaris independen dapat memperkuat pengaruh negatif antara CSR dan manajemen laba, perusahaan yang memiliki proporsi dewan komisaris independen yang tinggi akan mendorong manajer untuk lebih transparan dalam pelaporan kinerja dengan meningkatkan pengungkapan CSR dapat menuntut perusahaan tersebut untuk 
berperilaku lebih etis terhadap sosial dan lingkungan, selain itu komisaris independen dapat melakukan monitoring yang lebih intensif dan mengurangi kesempatan manajer untuk melakukan manajemen laba, sehingga dapat disimpulkan bahwa manajemen laba dapat dihalangi dengan adanya pengungkapan CSR dan proporsi dewan komisaris independen yang tinggi. Stakeholderakan lebih mempercayai dan mengandalkan laporan kinerja perusahaan yang memiliki pengungkapan sosial dan lingkungan yang lebih luas, dan perusahaan yang memiliki jumlah komisaris independennya lebih banyak sebagai pertimbangannya.

Tujuan ketiga dari penelitian ini adalah untuk menguji pengaruh pengungkapan kegiatan CSR terhadap manajemen laba dengan mempertimbangkan kepemilikan institusional. Hasil analisis menunjukkan bahwa terdapat efek interaksi pengungkapan CSR dan kepemilikan institusional pada hubungan antara pengungkapan CSR terhadap manajemen laba. Dengan demikian, dengan adanya persentase kepemilikan institusional yang tinggi dapat memperkuat hubungan negatif antara pengungkapan CSR dan manajemen laba terdukung secara statistik. Berdasarkan hasil penelitian ini dapat disimpulkan bahwa kepemilikan institusional dapat memperlemah pengaruh antara CSR dan manajemen laba, perusahaan yang memiliki proporsi kepemilikan saham oleh institusi lain, dapat mengawasi kinerja manajer dengan adanya voting power dan terlibat dalam pengambilan keputusan terkait pengungkapan kegiatan CSR karena adanya proporsi saham perusahaan yang dimiliki oleh institusi lain. Oleh karena itu, untuk mengurangi adanya kemungkinan tindakan oportunistik manajer,stakeholder dapat menuntut pengungkapan CSR yang lebih luas dan mempertimbangkan proporsi kepemilikan saham institusional.

\subsection{Keterbatasan Penelitian}

Terdapat keterbatasan yang melekat pada penelitian ini. Pertama, sampel dalam penelitian ini berasal dari perusahaan-perusahaan pertambangan saja, sehingga hasil penelitian ini belum tentu berlaku pada perusahaan-perusahaan diindustri lainnya. Kedua, penelitian ini menggunakan manajemen laba akrual, selain manajemen laba akrual dapat menggunakan pengukuran lain seperti manajemen aktivitas rill.

\subsection{Saran}

Terdapat beberapa saran yang berguna dalam melakukan penelitian-penelitian berikutnya, penelitian berikutnya dapat menggunakan objek diluar perusahaan pertambangan, seperti perusahaan perkebunan yang juga dapat menimbulkan dampak kerusakan lingkungan, dengan begitu dapat diteliti konsistensi temuan penelitian ini pada perusahaan-perusahaan di industri lain. Kedua, dapat mengembangkan penelitian dengan melihat tujuan dari manajemen laba akrual yang dilakukan (income smoothing, income decreasing, income agresif). Ketiga 
menggunakan model-model lain untuk mengukur manajemen laba, seperti pengukuran manajemen laba rill dan menggunakan indeks item pengungkapan CSR lain selain GRI versi 4, untuk meneliti konsistensi temuan penelitian ini dengan berbagai metode dan indeks item CSR yang digunakan.

\section{Daftar Pustaka}

Clarkson, P.M.,dan G. Richardson. 2008. Revisiting the Relation Between Environmenttal Performance and Environmental Disclosure: An Empirical Analysis. Accounting, Organisations and Society33 (8): 303-327.

Cornett, 2006. Earnings Manajement, Corporate Governance, and True Financial Performance', Working Paper. Boston College, Chestnut Hill, New York.

Dechow, P.M, R.G. Sloan., dan A.P. Sweeney. 1996. Causes and Consequences of Earnings Manipulation: Analysis of Firms Subject to Enforcement Actions by The SEC, Contemporary Accounting Research 13 (2): 1-36.

Fama, E.F.,danM.C. Jensen. 1983. Separation of Ownership and Control.Journal of Law and Economics26 (3): 1-325.

Fombrun, C.J., N.A. Gardberg., dan J.M. Sever. 2000. The Reputation Quotient: A Multistakeholder Measure of Corporate Reputation. Journal of Brand Manajement 7 (4): 41 255.

Gelb, D.S., dan A. Strawser. 2001. Corporate Social Responsibility and Financial Disclosure: An Alterna tive Explanation for Increased Disclosure.Journal of Business Ethics. 33 (5): 1-13.

Graves, S.B., dan S.A. Waddock. 1994.Institutional Owners and Corporate Social Performance. Academy of Manajement Journa/37(4): 1034-46.

Gray, R. 2005. Taking A Long View on What We Now Know About Social and Environmental Accountability and Reporting. Electronic Journal of Radical Organisation Theory9 (3): 131.

Gregory, H.J. 2000. Corporate Governance and the Role of the Board of Directors. Egon Zhender International.

Ghozali, I. 2009. Aplikasi Multivariate dengan Program SPSS, Badan Penerbit Universitas Diponegoro. Semarang.

Hackston, D.,dan J. Milne. 1996. Some Determinants Of Social And Environmental Disclosures In New Zaeland Companies. Accounting, Auditingand Accountability Journal9 (1): 77108.

Hermanto, W. 2013. Pengaruh Kepemilikan Institusional, Ukuran Perusahaan, Leverage terhadap Manajemen Laba (Studi Empiris pada Perusahaan Mnufaktur yang Terdaftar di BEI Tahun 2010-2013). Naskah publikasi Universitas Muhamadiah Surakarta.

Hong, Y., dan M.L. Andersen. 2011. The Relationship Between Corporate Social Responsibility and Earnings Manajement, An Exploratory Study.Journal of Business Ethics104 (4): 461- 471.

Jaggi, B., S. Leung., dan F. Gul. 2009. Family Control, Board Independence and Earnings Manajement: Evidence Based on Hong Kong Firms. Journal Account Public Policy28 (3): 281-300.

Jensen, M.C.,dan W.H Meckling. 1976. Theory Of The Firm: Manager Behavior, Agency Cost and Ownership Structure. Journal of Financial Economics 3 (5): 305-360. 
Jo, H., danA.M Harjoto. 2011. Corporate Governance and Firm Value: The Impact of Corporate Social Responsibility. Journal of Business Ethics 103 (3): 351-383.

Kim, Y., M.S Park, danB. Wier. 2012.Is Earnings Quality Associated with Corporate Social Responsibility?. The Accounting Review87 (3): 761-796.

Leuz, C., D. Nanda, dan P. Wysocki. 2003. Earnings Manajement and Investors Protection: An International Comparison. Journal of Financial Economics 69 (3): 505-527.

Patten, D.M.,dan G. Trompeter. 2003. Corporate Responses to Political Costs: An Examination of he Relation Between Environmental Disclosure and Earnings Manajement. Journal of Accounting and Public Policy 22 (2): 83-9.

Prior, D., J. Surroca., danJ.A Tribo. 2008. Are Socially Responsible Managers Really Ethical? Exploring the Relationship Between Earnings Manajement and Corporate Social Responsibility, Corporate Governance. An International Review(16) 3: 443-459.

Rice. 2013. Pengaruh Leverage, Kepemilikan Institusional, Ukuran dan Nilai Perusahaan terhadap Tindakan Manajemen Laba. Jurnal Wira Ekonomi Mikroskil (3)01: 41-50.

Scott, W.R. 2012. Financial Accounting Theory $6^{\text {th }}$ edition'. Toronto Pearson Education. Canada.

Shleifer, A.,dan R.W, Vishny. 1997. A Survey of Corporate Governance. Journal of Finance 52 (2): 737-783.

Shleifer, A. 2004. Does Competition Destroy Ethical Behavior?. Working Paper. Harvard University.

Sun, N., A. Salama., K. Hussainey., dan M. Habbash. 2010. Corporate Environmental Disclosure, Corporate Governance, and Earnings manajement. Managerial Auditing Journal25 (27): 679-700.

Young, W.O., Y.C Kyun., dan M. Aleksey. 2011.The Effect of Ownership Structure on Corporate Social Responsibility: Empirical Evidence from Korea. Journal of Business Ethics104 (3): 283-297.

Zahra, S.A., R.L Priem., danA.A Rasheed. 2005. The Antecedents and Consequences of Top Manajement Fraud. Journal of Manajement 31 (3): 803-28. 